\title{
A Compilation of Iron Speciation Data for Open Oceanic Waters
}

\author{
Salvatore Caprara ${ }^{1,2}$, Kristen N. Buck ${ }^{2}$, Loes J. A. Gerringa ${ }^{3}$, Micha J. A. Rijkenberg ${ }^{3}$ and \\ Damiano Monticelli ${ }^{1 *}$ \\ ${ }^{1}$ Dipartimento di Scienza e Alta Tecnologia, Università degli Studi dell'Insubria, Como, Italy, ${ }^{2}$ College of Marine Science, \\ University of South Florida, St. Petersburg, FL, USA, ${ }^{3}$ Department of Ocean Systems, Royal Netherlands Institute for Sea \\ Research, Utrecht University, Texel, Netherlands
}

Keywords: iron, speciation, organic ligand, seawater, dataset, metal titration

\section{INTRODUCTION}

Iron has been demonstrated to play a major role in limiting primary productivity in large areas of the ocean since the first formulation of the iron hypothesis (Martin, 1990). Efforts and papers devoted to this complex and multidisciplinary research topic (Jickells et al., 2005) saw an exponential increase over the last 25 years (Boyd and Ellwood, 2010). As a consequence, the latest available count (Tagliabue et al., 2016) tells us that the concentration of iron has been determined in

\section{OPEN ACCESS}

Edited by:

Antonio Tovar-Sanchez,

Spanish National Research Council,

Spain

Reviewed by:

Francisco Delgadillo-Hinojosa, Universidad Autónoma de Baja

California, Mexico

Juan Santos,

Instituto Español de Oceanografía,

Spain

*Correspondence:

Damiano Monticelli

damiano.monticelli@uninsubria.it

Specialty section:

This article was submitted to Marine Biogeochemistry, a section of the journal Frontiers in Marine Science

Received: 29 July 2016 Accepted: 25 October 2016 Published: 14 November 2016

Citation:

Caprara S, Buck KN, Gerringa LJA, Rijkenberg MJA and Monticelli D

(2016) A Compilation of Iron

Speciation Data for Open Oceanic

Waters. Front. Mar. Sci. 3:221.

doi: 10.3389/fmars.2016.00221 around 20,000 oceanic water samples up to 2014. After the noteworthy achievement of reliable iron concentration profiles, the interest of the scientific community moved on to try and understand the fast dynamic of this metal in oceanic waters. However, one of the main factors that determine the concentration of $\mathrm{Fe}$ in the oceans is its complexation to organic Fe-binding ligands: this is the reason why Fe speciation measurement made its way in the topic early (Gledhill and van den Berg, 1994; Rue and Bruland, 1995): research aims at establishing the role played by ligands in iron solubility, bioavailability and, as a whole, in its biogeochemical cycle (Hiemstra and van Riemsdijk, 2006; Hunter and Boyd, 2007; Boyd and Ellwood, 2010; Gledhill and Buck, 2012; Boyd and Tagliabue, 2015; Völker and Tagliabue, 2015). A higher iron solubility has since long been connected to the presence of strong binding ligands (Johnson et al., 1997; Liu and Millero, 2002): whether this implies a higher productivity, i.e., an increase in the bioavailable fraction, is still a matter of investigation and strongly depends on the nature of the ligands (Chen and Wang, 2008; Boyd and Ellwood, 2010; Gledhill and Buck, 2012; Shaked and Lis, 2012). An attempt to directly model the dynamics of iron binding ligands in oceanic waters has been recently presented (Völker and Tagliabue, 2015).

The possibility to understand and correctly account for the biogeochemistry of iron in the oceans relies on the quality of the data. Robust analytical methods are clearly needed in speciation studies: the best performances in term of detection capabilities, selectivity, matrix tolerance and clean techniques are mandatory to achieve reliable results. In particular, competitive ligand equilibration coupled to adsorptive cathodic stripping voltammetry (CLE-AdCSV) has been invariantly used to characterize iron complexing species, i.e., the concentration of the ligand and the conditional stability constant for the formation of the iron-ligand complex (structural characterization is outside the aim of this data report: the interested reader is referred to recent papers on this topic Gledhill and Buck, 2012; Boiteau et al., 2013). Four different artificial ligands have been used for the CLE-AdCSV procedure: 1-nitroso-2-napthol, NN (Gledhill and van den Berg, 1994); salicylaldoxime, SA, originally developed in 1995 (Rue and Bruland, 1995) and revised in 2014 (Abualhaija and van den Berg, 2014); 2-(2-thiazolylazo)-p-cresol, TAC (Croot and Johansson, 2000) and dihydroxynaphthalene, DHN (van den Berg, 2006). The importance of a correct analysis of the resulting CLE-CSV titration data and the assessment of its errors is the final critical step in this procedure (Monticelli et al., 2010; Laglera et al., 2013; Gerringa et al., 2014; Pižeta et al., 2015). 
The present data report aims at making published data on ligand concentration in open oceanic waters available to the scientific community to foster the understanding of the role played by natural ligand in iron biogeochemical cycle. As per the nature of the data report paper, only a preliminary discussion of the data is presented in the form of possible uses of the dataset.

\section{DESCRIPTION OF THE DATASET}

The dataset "Iron speciation dataset.xlsx" can be found following this permanent link https://figshare.com/s/ 6572ca173695f4a03738. Data were collected from published papers: pre-2012 papers were obtained from a recent review on the subject (Gledhill and Buck, 2012), whereas literature searches were employed for post-2012 research articles. The dataset covers the 1994-2015 timespan (papers published in 2016 are not included). Source papers are reported in Table 1 together with the investigated region, the filter cutoff employed, the nature of the added ligand and the data treatment.

The dataset includes observations for open oceanic waters only, i.e., off-shelf sampling locations. Open ocean data were selected and in-shelf, costal, estuarine and closed basin data (Mediterranean Sea, Black Sea, etc.) were excluded. Data obtained during fertilization experiments were also excluded: only off-patch or pre-fertilization data were included from those studies. Analogously, data from waters sampled in areas close to hydrothermal vents or thawing ice were not included. The idea is to create a consistent dataset, trying and collecting a tentatively homogeneous set of data. Most of the data were directly available as electronic datasets, whereas a few, mainly the oldest ones, had to be digitized from figures.

The iron speciation dataset includes around 1732 iron speciation data, organized by chronological order. In particular, we reported for each data point (whenever available): the reference in the form author-year, the sampling date, depth, and location (as decimal degrees), dissolved iron concentration (DFe, $\mathrm{nM}$ ), the logarithm of the side coefficient for the formation of the iron-added ligand complex $\left(\log \alpha_{F^{\prime} A L}\right)$, ligand concentration (nM) and the logarithm of the conditional stability constant for the formation of the iron-ligand complex $\left(\log K_{F e L, F e}^{c o n d}\right)$. The latter are reported as both $K_{\mathrm{FeL}, \mathrm{Fe} e^{3+}}^{\mathrm{cond}}$ and $K_{\mathrm{FeL}, \mathrm{Fe}}^{\mathrm{cond}}$ : to normalize data, $K_{\mathrm{FeL}, \mathrm{Fe} e^{3+}}^{\mathrm{cond}}$ were transformed to $K_{\mathrm{FeL}, \mathrm{Fe}^{\prime}}^{\mathrm{cond}}$ using a factor of $10^{10}$ for the inorganic alpha, $\alpha_{F e^{\prime}}$ (Hudson et al., 1992). The green filled cells in the dataset signal that $K_{\mathrm{FeL}, \mathrm{Fe}^{3+}}^{\mathrm{cond}}$ was originally reported in those papers, and was converted to $K_{\mathrm{FeL}, \mathrm{Fe} e^{\prime}}^{c o n}$ here. When more than one ligand class was determined, their concentrations and conditional stability constants are reported in additional columns. We follow the common practice to use the simplified expression "ligand concentration" and use the nanomolar concentration unit, although we should properly indicate binding sites and use the nanoequivalent of $\mathrm{nM}$ iron as the unity of measurement. The employed filter cutoff for each study is reported in Table 1: in case ligands were determined in more than one size fraction, the additional data are reported in the second sheet of the dataset named "Size Fractionated," together with the filter cutoff employed.

\section{DATA PRESENTATION AND DISCUSSION}

The dataset is intended to provide marine scientists and the broader community with the published data for iron ligand characteristics. In the following sections, we present different cuts through the data showing different possible uses of the dataset. A detailed discussion of the data is nevertheless outside the aim of the present data report: only general trends (or their absence) will be presented.

A first evidence from the dataset is the strongly uneven distribution of the data: 1185 out of 1732 data are from Atlantic Ocean waters, 232 from the Pacific, 214 from the Indian Ocean and the remaining ones from Polar regions, 51 from the Arctic ( $\mathrm{N}$ of the Arctic Circle) and 50 from the Southern Ocean (south of $60^{\circ} \mathrm{S}$ ). Accordingly, any discussion of this dataset is necessarily biased and reflects the features of the basins where the samples were collected.

Checking for consistency in the procedure or for the presence of bias is a possible way to extract information from the data. Figure 1A shows the measured side reaction coefficient $\alpha_{F e^{\prime} L}$ (defined as the product of the conditional stability constant $K_{F e L, F e^{\prime}}^{c o n d}$ and the free ligand concentration $\left[\mathrm{L}^{\prime}\right], \alpha_{F^{\prime} L}=K_{F e L, F e^{\prime}}^{c o n d}$. $\left.\left[\mathrm{L}^{\prime}\right]\right)$ as a function of the side reaction coefficient $\alpha_{F e^{\prime} A L}$, the alpha coefficient for the complexation of iron by the added ligand as obtained from the relevant papers $\left(\left[\mathrm{L}^{\prime}\right]\right.$ was calculated from the data by standard thermodynamic calculations van den Berg and Donat, 1992). The lowest and the two highest $\alpha_{F e^{\prime} A L}$ employed show very good agreement between the experimental data and their expected detection windows defined as the range 0.1-10 $\alpha_{F e^{\prime} A L}$ (van den Berg et al., 1990). The four central competition strengths with $1.86<\log \alpha_{F e^{\prime} A L}<2.5$ show most of their data outside the traditionally suggested upper limit for the detection window. This apparent discrepancy should be discussed in light of different factors: (1) the definition of the detection window as the range $0.1-10 \alpha_{F^{\prime} A L}$ is an approximate estimation defining the optimal range for the CLE methods: several studies demonstrated that a three orders of magnitude window is a more realistic estimate (Apte et al., 1988); (2) the choice of the method to treat/transform the data obtained from the titrations impacts the results, distinctively when more than one ligand class is calculated (Laglera et al., 2013; Pižeta et al., 2015) and may alter the traditionally agreed idea about the position and width of the detection window. This point is anyhow worth of future investigation. Conversely, figures lower than the expected lowest limit of the detection window may be easily explained by the saturation of the natural ligands at ambient iron concentrations.

A further interesting point is the possibility that the difference in the data is due to the authors employing different analytical procedures, including different data treatment. The lack of standardization and validation protocols in this field, caused by the absence of reference material and the shortage of routine interlaboratory exercises, makes this risk sensible (see also the Conclusion section). Analysis of variance (ANOVA) conducted 
TABLE 1 | Data sources for the iron speciation database listed in chronological order.

\begin{tabular}{|c|c|c|c|c|c|c|}
\hline Region & AL & AL conc $(\mu M)$ & log alpha $F e^{\prime} A L$ & $\begin{array}{c}\text { Fraction } \\
\text { (pore size, } \mu \mathrm{m})\end{array}$ & Data treatment & References \\
\hline Atlantic Ocean & NN & $1 ; 5$ & $1.9 ; 2.5$ & 0.45 & van den Berg Ružić & $\begin{array}{l}\text { Gledhill and van den Berg, } \\
1994\end{array}$ \\
\hline Central N Pacific & SA & 27.5 & 1.86 & 0.2 & van den Berg Ružić & Rue and Bruland, 1995 \\
\hline Pacific Southern Ocean & NN & 1 & 1.9 & 0.45 & non-linear Gerringa & Nolting et al., 1998 \\
\hline NW Atlantic & NN & 20 & 3.04 & 0.2 & $\begin{array}{l}\text { van den Berg Ružić and } \\
\text { non-linear Gerringa }\end{array}$ & Witter and Luther, 1998 \\
\hline NE Indian & NN & 20 & 3.04 & 0.4 & van den Berg Ružić & Witter et al., 2000 \\
\hline Atlantic Southern Ocean & NN & 5 & 2.5 & 0.2 & van den Berg Ružić & Boye et al., 2001 \\
\hline S and Equatorial Atlantic & SA & 30 & 1.94 & 0.22 & Non-linear Gerringa & Powell and Donat, 2001 \\
\hline NE Atlantic & NN & 5 & 2.5 & 0.2 & van den Berg Ružić & Boye et al., 2003 \\
\hline \multirow[t]{2}{*}{ Atlantic Southern Ocean } & TAC & 10 & 2.4 & 0.4 & Non-linear Gerringa & Croot et al., 2004 \\
\hline & NN & $5 ; 10 ; 20$ & $2.4 ; 3.4 ; 4.3$ & 0.4 & & \\
\hline Atlantic Southern Ocean & TAC & 10 & 2.4 & 0.2 & van den Berg Ružić & Boye et al., 2005 \\
\hline NE Atlantic & NN & 5 & 2.5 & 0.2 & van den Berg Ružić & Boye et al., 2006 \\
\hline Atlantic Ocean & TAC & 10.6 & 2.45 & 0.2 & Non-linear Gerringa & Cullen et al., 2006 \\
\hline NE Atlantic & TAC & 10 & 2.4 & 0.2 & Non-linear Gerringa & Gerringa et al., 2006 \\
\hline Pacific Southern Ocean & TAC & 10 & 2.4 & 0.2 & Non-linear Gerringa & Tian et al., 2006 \\
\hline Pacific Ocean & $\mathrm{DHN}$ & $0.5 ; 1$ & $2.22 ; 2.56$ & 0.1 & van den Berg Ružić & van den Berg, 2006 \\
\hline Tropical North Pacific & TAC & 10 & 2.4 & 0.4 & van den Berg Ružić & Hopkinson and Barbeau, 2007 \\
\hline Sulu Sea (Tropical N Pacific) & TAC & 10 & 2.4 & 0.22 & van den Berg Ružić & Kondo et al., 2007 \\
\hline Indian Southern Ocean & TAC & 10 & 2.4 & 0.2 & Non-linear Gerringa & Gerringa et al., 2008 \\
\hline Tropical N Atlantic & TAC & 10 & 2.4 & 0.2 & Non-linear Gerringa & Rijkenberg et al., 2008 \\
\hline Antarctic polar Front & TAC & 10 & 2.4 & 0.2 & van den Berg Ružić & Boye et al., 2010 \\
\hline NE Atlantic & TAC & 10 & 2.4 & 0.2 & Non-linear Gerringa & Thuróczy et al., 2010 \\
\hline Indian Southern Ocean & TAC & 10 & 2.4 & 0.4 & Non-linear Gerringa & Ibisanmi et al., 2011 \\
\hline N Atlantic & TAC & 10 & 2.4 & 0.2 & Non-linear Gerringa & Mohamed et al., 2011 \\
\hline Arctic Ocean & TAC & 10 & 2.4 & 0.2 & Non-linear Gerringa & Thuróczy et al., 2011a \\
\hline Atlantic Southern Ocean & TAC & 10 & 2.4 & 0.2 & Non-linear Gerringa & Thuróczy et al., 2011b \\
\hline Central Pacific & TAC & 10 & 2.4 & 0.22 & Non-linear Gerringa & Kondo et al., 2012 \\
\hline Atlantic Southern Ocean & TAC & 10 & 2.4 & 0.2 & Non-linear Gerringa & Schlosser et al., 2012 \\
\hline Atlantic Southern Ocean & TAC & 10 & 2.4 & 0.2 & Non-linear Gerringa & Thuróczy et al., 2012 \\
\hline N Atlantic & SA & 27.5 & 1.86 & 0.2 & $\begin{array}{l}\text { van den Berg Ružić and } \\
\text { Scatchard }\end{array}$ & Buck et al., 2015 \\
\hline Atlantic Ocean & SA & $25 ; 32.5$ & $1.78 ; 2.00$ & 0.2 & $\begin{array}{l}\text { van den Berg Ružić and } \\
\text { Scatchard }\end{array}$ & Fitzsimmons et al., 2015a \\
\hline Pacific Ocean & SA & 25 & 1.77 & 0.4 & $\begin{array}{l}\text { van den Berg Ružić and } \\
\text { Scatchard }\end{array}$ & Fitzsimmons et al., 2015b \\
\hline W Atlantic & TAC & 10 & 2.4 & 0.2 & Non-linear Gerringa & Gerringa et al., 2015 \\
\hline
\end{tabular}

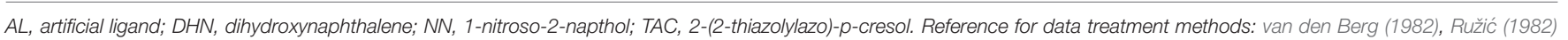
and Scatchard (1949), non-linear Gerringa et al. (1995) reviewed in 2014 Gerringa et al. (2014).

separately on the ligand concentration $\left(\mathrm{C}_{\mathrm{L}}\right)$ and $\log K_{\mathrm{FeL}, F e^{\prime}}^{c o n d}$ data, revealed that the null hypothesis of equal values obtained by the authors should be rejected $\left(\log K_{F e L, F e^{\prime}}^{c o n d}: n=1618, F=43, p<\right.$ $\left.0.05 ; \mathrm{C}_{\mathrm{L}}: n=1725, F=71, p<0.05\right)$. These results are not clearly conclusive about any presence of bias among the authors or the analytical procedures, as different samples were analyzed by authors, although some of the oldest, pre-2000 data seem to show lower $\log K_{\mathrm{FeL}, \mathrm{Fe}}^{\mathrm{cond}}$ and higher $\mathrm{C}_{\mathrm{L}}$. Application to a more homogeneous subset of data, e.g., different procedures for the same basin, could result in more definite inferences.
The relationship between iron and ligand concentrations is presented in Figure 1B. Beside the presence of some outliers, the linear correlation is significant $(n=1727, r=0.445, p<0.01)$ : the intercept $(0.87 \pm 0.033)$ and the slope $(0.92 \pm 0.044)$ point to an average excess of $0.9 \mathrm{nM}$ ligand with respect to total iron concentration, irrespective of total $\mathrm{Fe}$ as evidenced by the almost 1:1 increase of ligand with iron concentration. This linear model does not imply any cause/effect relationship between the two parameters and it is intended to be descriptive rather than predictive. 

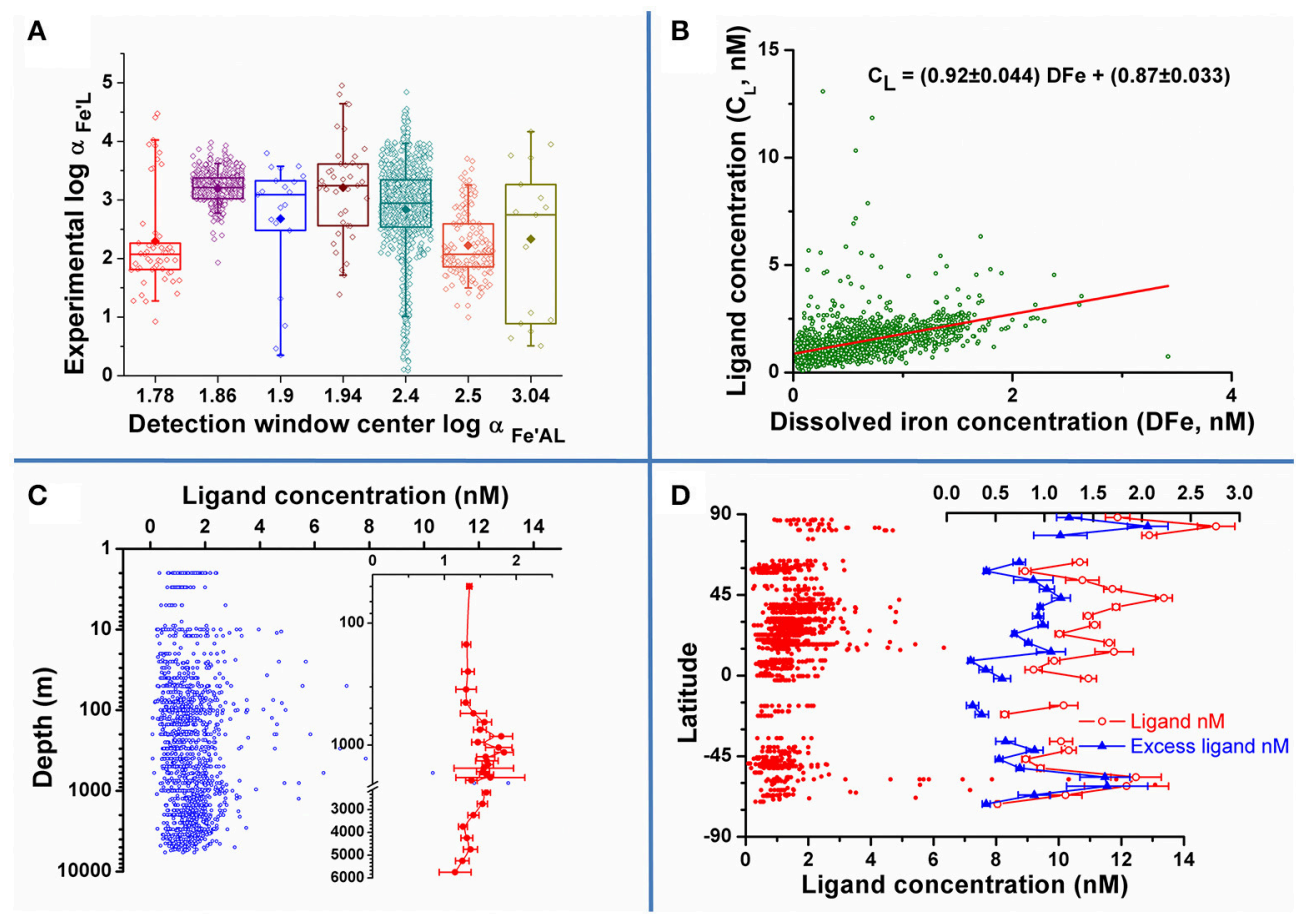

FIGURE 1 | (A) Calculated $\alpha_{F e^{\prime} L}$ as a function of the center of the detection windows $\alpha_{F e^{\prime} A L}$ : data are reported as open symbol with average as full symbol (data range: box 25-75 percentile, whiskers: 5-95 percentile); (B-D), concentration of ligands as a function of dissolved iron concentration (B), depth (C) and latitude (D). Excess ligand concentrations were computed by standard thermodynamic equations, i.e., the expression of the equilibrium constant and the mass balances for the involved species.

Figure 1C depicts the concentration of ligands for oceanic waters as a function of depth (note the log scale on the y-axis used to show possible trends in the upper part of the water column). No clear global trend emerges from open ocean data reported in the literature. The averaged data (see inset) shows a very uniform value down to a depth of $500 \mathrm{~m}$, an enrichment in mid depth waters ( $<500 \mathrm{~m}$ to around $2000 \mathrm{~m}$ ), possibly due to the remineralization of organic matter at these depths, and a decrease thereafter down to values similar to the ones determined in the upper part of the water column. This trend is anyhow hardly significant standing the variability in the data evidenced by their standard deviation (error bars in the graph represents the standard deviation of the mean): any strong depth trend on the global scale seems to be absent, although a higher variability of ligand concentrations in mid depth waters emerges.

As a final example of possible global trends, data for ligand concentrations on the entire water column as a function of sampling latitude are reported in Figure 1D (data averaged on a 5 degree base in the right section of the figure). Notwithstanding the high variability in the data, northern hemisphere waters are on average richer in ligands than the Austral ones, as already observed for Atlantic water samples (Gerringa et al., 2015). More detailed, northern hemisphere waters seem to show alternating minima and maxima in ligand concentrations: a minimum right North of the Equator (0-10 degrees), an enriched area extending up to mid latitudes (10-50 degrees), another minimum around $60^{\circ}$ and again higher concentrations in the Arctic Ocean. A similar trend is observed for the excess ligand concentrations. Depleted and enriched areas are also present in the Austral hemisphere waters, although the limited number of data calls for caution in stating any trend.

\section{CONCLUSIONS}

The collection of published data on iron ligand concentrations is a first mandatory step in understanding the role played by iron ligands in the biogeochemical oceanic cycle of this element. The overall picture emerging from the data is the ubiquitous presence of ligands in open oceanic waters, with an average $\sim 0.9 \mathrm{nM}$ excess with respect to dissolved iron concentration. Depth profiles show little to no tendency on a global averaged scale, whereas latitudinal trends are clearly visible, with northern hemisphere waters enriched in iron ligands (samples from the Atlantic Ocean mainly). As far as the Atlantic is concerned, ligands contributed to the Arctic by tributary rivers have been recently put forward as an explanation for this latitudinal trend (Gerringa et al., 2015).

Several points should be addressed before an exhaustive and reliable picture of the topic may be achieved and data used for the understanding of the iron cycle or its modeling. The first issue is that available data are strongly biased: around $70 \%$ of the samples were collected in the Atlantic Ocean and any conclusion is accordingly strongly biased by the provenance 
of the samples. Accordingly, representative sampling of world oceanic waters is the major gap to be filled: the GEOTRACES program (www.geotraces.org) is expected to contribute much to this aim. A second class of fundamental issues is related to the analytical procedures, their validation and reliability. Analytical procedures are cumbersome at the moment, requiring large volume of samples $(120-150 \mathrm{~mL})$ and $3-5 \mathrm{~h}$ of analysis time. Recent advancement in methods for total iron determination including reduction in sample size and analysis time (Caprara et al., 2015) may strongly contribute in the definition of higher performance speciation procedures, although at the moment the method was only validated for dissolved iron determination and not for the CLE-CSV procedure. Standing the difficulties in validating the employed analytical methods as standard reference materials are not available, calibration of the procedures may be achieved by intercomparison exercises, i.e., analyzing real or simulated samples distributed among participating laboratories. Data treatment should be included in this calibration procedure because of its value in achieving reliable results (Hudson et al., 2003; Laglera et al., 2013; Gerringa et al., 2014; Laglera and Filella, 2015; Pižeta et al., 2015). This process would ensure that results obtained by different laboratories are traceable to a common set of interlaboratory samples. Unfortunately, this procedure is not common practice at present, although

\section{REFERENCES}

Abualhaija, M. M., and van den Berg, C. M. G. (2014). Chemical speciation of iron in seawater using catalytic cathodic stripping voltammetry with ligand competition against salicylaldoxime. Mar. Chem. 164, 60-74. doi: 10.1016/j.marchem.2014.06.005

Apte, S. C., Gardner, M. J., and Ravenscroft, J. E. (1988). An evaluation of voltammetric titration procedures for the determination of trace metal complexation in natural waters by use of computers simulation. Anal. Chim. Acta 212, 1-21. doi: 10.1016/S0003-2670(00)84124-0

Boiteau, R. M., Fitzsimmons, J. N., Repeta, D. J., and Boyle, E. A. (2013). Detection of iron ligands in Seawater and Marine Cyanobacteria cultures by high-performance liquid chromatography-inductively coupled plasma-mass spectrometry. Anal. Chem. 85, 4357-4362. doi: 10.1021/ac3034568

Boyd, P. W., and Ellwood, M. J. (2010). The biogeochemical cycle of iron in the ocean. Nat. Geosci. 3, 675-682. doi: 10.1038/ngeo964

Boyd, P. W., and Tagliabue, A. (2015). Using the L* concept to explore controls on the relationship between paired ligand and dissolved iron concentrations in the ocean. Mar. Chem. 173, 52-66. doi: 10.1016/j.marchem.2014.12.003

Boye, M., Aldrich, A., van den Berg, C. M. G., de Jong, J. T. M., Nirmaier, H., Veldhuis, M., et al. (2006). The chemical speciation of iron in the northeast Atlantic Ocean. Deep-Sea Res. I Oceanogr. Res. Pap. 53, 667-683. doi: 10.1016/j.dsr.2005.12.015

Boye, M. B., Aldrich, A. P., van den Berg, C. M. G., de Jong, J. T. M., Veldhuis, M. J. W., and de Baar, H. J. W. (2003). Horizontal gradient of the chemical speciation of iron in surface waters of N.E. Atlantic Ocean. Mar. Chem. 80, 129-143. doi: 10.1016/S0304-4203(02)00102-0

Boye, M., Nishioka, J., Croot, P., Laan, P., Timmermans, K. R., Strass, V. H., et al. (2010). Significant portion of dissolved organic Fe complexes in fact is Fe colloids. Mar. Chem. 122, 20-27. doi: 10.1016/j.marchem.2010.09.001

Boye, M., Nishioka, J., Croot, P. L., Laan, P., Timmermans, K. R., and de Baar, H. J. W. (2005). Major deviations of iron complexation during 22 days of a mesoscale iron enrichment in the open Southern Ocean. Mar. Chem. 96, 257-271. doi: 10.1016/j.marchem.2005.02.002 intercalibration cruises have been organized (Buck et al., 2012) and results of a GEOTRACES cross-over station for ligands is submitted together with this paper (Buck et al., unpublished). A further related issue is the correlation between sampling areas and authors: any bias among the procedures used by different authors is at risk of resulting in erroneous evaluations of spatial trends.

\section{AUTHOR CONTRIBUTIONS}

All the authors contributed to this study. SC: Built the database; $\mathrm{KB}$, LG, and MR: Contributed to the writing and correction of the manuscript; DM: Devised the data report, did the bibliographic research and drafted the manuscript. All the five authors reviewed the final version of the manuscript and contributed to the discussion of the data.

\section{FUNDING}

DM acknowledges Università degli Studi dell'Insubria, project FAR2015 KB was supported by a U.S. National Science Foundation award, OCE-1441969 LG and MR acknowledge the Dutch funding agency ZKO (project number 839.08.410) of the National Science Foundation NWO for funding.

Boye, M., van den Berg, C. M. G., de Jong, J. T. M., Leach, H., Croot, P., and de Baar, H. J. W. (2001). Organic complexation of iron in the Southern Ocean. Deep-Sea Res. I Oceanogr. Res. Pap. 48, 1477-1497. doi: 10.1016/S0967-0637(00) 00099-6

Buck, K. N., Moffett, J., Barbeau, K. A., Bundy, R. M., Kondo, Y., and $\mathrm{Wu}$, J. (2012). The organic complexation of iron and copper: An intercomparison of competitive ligand exchange-adsorptive cathodic stripping voltammetry (CLE-ACSV) techniques. Limnol. Oceanogr. 10, 496-515. doi: 10.4319/lom.2012.10.496

Buck, K. N., Sohst, B., and Sedwick, P. N. (2015). The organic complexation of dissolved iron along the U.S. GEOTRACES (GA03) North Atlantic Section. Deep-Sea Res. Part II: Top. Stud. Oceanogr. 116, 152-165. doi: 10.1016/j.dsr2.2014.11.016

Caprara, S., Laglera, L. M., and Monticelli, D. (2015). Ultrasensitive and Fast Voltammetric Determination of Iron in Seawater by Atmospheric Oxygen Catalysis in $500 \mu \mathrm{l}$ Samples. Anal. Chem. 87, 6357-6363. doi: 10.1021/acs.analchem.5b01239

Chen, M., and Wang, W.-X. (2008). Accelerated uptake by phytoplankton of iron bound to humic acids. Aquat. Biol. 3:155-166. doi: 10.3354/ab00064

Croot, P. L., Andersson, K., Öztürk, M., and Turner, D. R. (2004). The distribution and speciation of iron along $6^{\circ} \mathrm{E}$ in the Southern Ocean. Deep-Sea Res. II 51, 2857-2879. doi: 10.1016/j.dsr2.2003.10.012

Croot, P. L., and Johansson, M. (2000). Determination of iron speciation by cathodic stripping voltammetry in seawater using the competing ligand 2-(2-thiazolylazo)-p-cresol (TAC). Electroanalysis 12, 565-576. doi: 10.1002/(SICI)1521-4109(200005)12:8<565::AID-ELAN565>3.0.CO;2-L

Cullen, J. T., Bergquist, B. A., and Moffett, J. W. (2006). Thermodynamic characterization of the partitioning of iron between soluble and colloidal species in the Atlantic Ocean. Mar. Chem. 98, 295-303. doi: 10.1016/j.marchem.2005.10.007

Fitzsimmons, J. N., Bundy, R. M., Al-Subiai, S. N., Barbeau, K. A., and Boyle, E. A. (2015a). The composition of dissolved iron in the dusty surface ocean: an exploration using size-fractionated iron-binding ligands. Mar. Chem. 173, 125-135. doi: 10.1016/j.marchem.2014.09.002 
Fitzsimmons, J. N., Hayes, C. T., Al-Subiai, S. N., Zhang, R., Morton, P. L., Weisend, R. E., et al. (2015b). Daily to decadal variability of sizefractionated iron and iron-binding ligands at the Hawaii Ocean Timeseries Station ALOHA. Geochim. Cosmochim. Acta 171, 303-324. doi: 10.1016/j.gca.2015.08.012

Gerringa, L. J. A., Blain, S., Laan, P., Sarthou, G., Veldhuis, M. J. W., Brussaard, C. P. D., et al. (2008). Fe-binding dissolved organic ligands near the Kerguelen Archipelago in the Southern Ocean (Indian sector). Deep-Sea Res. Part II: Top. Stud. Oceanogr. 55, 606-621. doi: 10.1016/j.dsr2.2007.12.007

Gerringa, L. J. A., Rijkenberg, M. J. A., Schoemann, V., Laan, P., and de Baar, H. J. W. (2015). Organic complexation of iron in the West Atlantic Ocean. Mar. Chem. 177, 434-446. doi: 10.1016/j.marchem.2015.04.007

Gerringa, L. J. A., Rijkenberg, M. J. A., Thuróczy, C. E., and Maas, L. R. M. (2014). A critical look at the calculation of the binding characteristics and concentration of iron complexing ligands in seawater with suggested improvements. Environ. Chem. 11, 114-136. doi: 10.1071/EN13072

Gerringa, L. J. A., Veldhuis, M. J. W., Timmermans, K. R., Sarthou, G., and de Baar, H. J. W. (2006). Co-variance of dissolved Fe-binding ligands with phytoplankton characteristics in the Canary Basin. Mar. Chem. 102, 276-290. doi: 10.1016/j.marchem.2006.05.004

Gerringa, L. J., Herman, P. M., and Poortvliet, T. C. (1995). Comparison of the linear Van den Berg/Ruzic transformation and a non-linear fit of the Langmuir isotherm applied to $\mathrm{Cu}$ speciation data in the estuarine environment. Mar. Chem. 48, 131-142. doi: 10.1016/0304-4203(94)00041-B

Gledhill, M., and Buck, K. N. (2012). The organic complexation of iron in the marine environment: a review. Front. Microbiol. 3:69. doi: 10.3389/fmicb.2012.00069

Gledhill, M., and van den Berg, C. M. G. (1994). Determination of complexation of iron(III) with natural organic complexing ligands in seawater using cathodic stripping voltammetry. Mar. Chem. 47, 41-54. doi: 10.1016/03044203(94)90012-4

Hiemstra, T., and van Riemsdijk, W. H. (2006). Biogeochemical speciation of Fe in ocean water. Mar. Chem. 102, 181-197. doi: 10.1016/j.marchem.2006.03.008

Hopkinson, B. M., and Barbeau, K. A. (2007). Organic and redox speciation of iron in the eastern tropical North Pacific suboxic zone. Mar. Chem. 106, 2-17. doi: 10.1016/j.marchem.2006.02.008

Hudson, R. J. M., Covault, D. M., and Morel, F. M. M. (1992). Investigations of iron coordination and redox reactions in seawater using 59Fe radiometry and ionpair sovent extraction of amphiphilic iron complexes. Mar. Chem. 38, 209-235. doi: 10.1016/0304-4203(92)90035-9

Hudson, R. J. M., Rue, E. L., and Bruland, K. W. (2003). Modeling complexometric titrations of natural water samples. Environ. Sci. Technol. 37, 1553-1562. doi: $10.1021 /$ es025751a

Hunter, K. A., and Boyd, P. W. (2007). Iron-binding ligands and their role in the ocean biogeochemistry of iron. Environ. Chem. 4, 221-232. doi: $10.1071 /$ EN07012

Ibisanmi, E., Sander, S. G., Boyd, P. W., Bowie, A. R., and Hunter, K. A. (2011). Vertical distributions of iron-(III) complexing ligands in the Southern Ocean. Deep-Sea Res. II Top. Stud. Oceanogr. 58, 2113-2125. doi: 10.1016/j.dsr2.2011.05.028

Jickells, T. D., An, Z. S., Andersen, K. K., Baker, A. R., Bergametti, C., Brooks, N., et al. (2005). Global iron connections between desert dust, ocean biogeochemistry, and climate. Science 308, 67-71. doi: 10.1126/science.1105959

Johnson, K. S., Michael Gordon, R., and Coale, K. H. (1997). What controls dissolved iron concentrations in the world ocean? Mar. Chem. 57, 137-161.

Kondo, Y., Takeda, S., and Furuya, K. (2007). Distribution and speciation of dissolved iron in the Sulu Sea and its adjacent waters. Deep-Sea Res. II Top. Stud. Oceanogr. 54, 60-80. doi: 10.1016/j.dsr2.2006.08.019

Kondo, Y., Takeda, S., and Furuya, K. (2012). Distinct trends in dissolved Fe speciation between shallow and deep waters in the Pacific Ocean. Mar. Chem. 134-135, 18-28. doi: 10.1016/j.marchem.2012.03.002

Laglera, L. M., Downes, J., and Santos-Echeandía, J. (2013). Comparison and combined use of linear and non-linear fitting for the estimation of complexing parameters from metal titrations of estuarine samples by CLE/AdCSV. Mar. Chem. 155, 102-112. doi: 10.1016/j.marchem.2013.06.005

Laglera, L. M., and Filella, M. (2015). The relevance of ligand exchange kinetics in the measurement of iron speciation by CLE-AdCSV in seawater. Mar. Chem. 173, 100-113. doi: 10.1016/j.marchem.2014.09.005
Liu, X. W., and Millero, F. J. (2002). The solubility of iron in seawater. Mar. Chem. 77, 43-54. doi: 10.1016/S0304-4203(01)00074-3

Martin, J. H. (1990). Glacial-interglacial CO2 change: the iron hypothesis. Paleoceanography 5, 1-13. doi: 10.1029/PA005i001p00001

Mohamed, K. N., Steigenberger, S., Nielsdottir, M. C., Gledhill, M., and Achterberg, E. P. (2011). Dissolved iron(III) speciation in the high latitude North Atlantic Ocean. Deep-Sea Res. I Oceanogr. Res. Pap. 58, 1049-1059. doi: 10.1016/j.dsr.2011.08.011

Monticelli, D., Dossi, C., and Castelletti, A. (2010). Assessment of accuracy and precision in speciation analysis by competitive ligand equilibration-cathodic stripping voltammetry (CLE-CSV) and application to Antarctic samples. Anal. Chim. Acta 675, 116-124. doi: 10.1016/j.aca.2010.07.009

Nolting, R. F., Gerringa, L. J. A., Swagerman, M. J. W., Timmermans, K. R., and De Baar, H. J. W. (1998). Fe (III) speciation in the high nutrient, low chlorophyll Pacific region of the Southern Ocean. Mar. Chem. 62, 335-352. doi: 10.1016/S0304-4203(98)00046-2

Pižeta, I., Sander, S. G., Hudson, R. J. M., Omanović, D., Baars, O., Barbeau, K. A., et al. (2015). Interpretation of complexometric titration data: An intercomparison of methods for estimating models of trace metal complexation by natural organic ligands. Mar. Chem. 173, 3-24. doi: 10.1016/j.marchem.2015.03.006

Powell, R. T., and Donat, J. R. (2001). Organic complexation and speciation of iron in the South and equatorial Atlantic. Deep Sea Res. Part II Top. Stud. Oceanogr. 48, 2877-2893. doi: 10.1016/S0967-0645(01)00022-4

Rijkenberg, M. J. A., Powell, C. F., Dall'Osto, M., Nielsdottir, M. C., Patey, M. D., Hill, P. G., et al. (2008). Changes in iron speciation following a Saharan dust event in the tropical North Atlantic Ocean. Mar. Chem. 110, 56-67. doi: 10.1016/j.marchem.2008.02.006

Rue, E. L., and Bruland, K. W. (1995). Complexation of iron(III) by natural organic ligands in the Central North Pacific as determined by a new competitive ligand equilibration adsorptive cathodic stripping voltammetric method. Mar. Chem. 50, 117-138. doi: 10.1016/0304-4203(95)00031-L

Ružić, I. (1982). Theoretical aspects of the direct titration of natural waters and its information yield for trace metal speciation. Anal. Chim. Acta 140, 99-113. doi: 10.1016/S0003-2670(01)95456-X

Scatchard, G. (1949). The attractions of proteins for small molecules and ions. Ann. N. Y. Acad. Sci. 51, 660-672. doi: 10.1111/j.1749-6632.1949.tb27297.x

Schlosser, C., de la Rocha, C. L., Streu, P., and Croot, P. L. (2012). Solubility of iron in the Southern Ocean. Limnol. Oceanogr. 57, 684-697. doi: 10.4319/lo.2012.57.3.0684

Shaked, Y., and Lis, H. (2012). Disassembling iron availability to phytoplankton. Front. Microbiol. 3:123. doi: 10.3389/fmicb.2012.00123

Tagliabue, A., Aumont, O., DeAth, R., Dunne, J. P., Dutkiewicz, S., Galbraith, E., et al. (2016). How well do global ocean biogeochemistry models simulate dissolved iron distributions? Glob. Biogeochem. Cycles 30, 149-174. doi: 10.1002/2015GB005289

Thuróczy, C. E., Alderkamp, A. C., Laan, P., Gerringa, L. J. A., Mills, M. M., Van Dijken, G. L., et al. (2012). Key role of organic complexation of iron in sustaining phytoplankton blooms in the Pine Island and Amundsen Polynyas (Southern Ocean). Deep-Sea Res. Part II Top. Stud. Oceanogr. 71-76, 49-60. doi: 10.1016/j.dsr2.2012.03.009

Thuróczy, C. E., Gerringa, L. J. A., Klunder, M. B., Laan, P., and de Baar, H. J. W. (2011b). Observation of consistent trends in the organic complexation of dissolved iron in the Atlantic sector of the Southern Ocean. Deep Sea Res. Part II Top. Stud. Oceanogr. 58, 2695-2706. doi: 10.1016/j.dsr2.2011. 01.002

Thuróczy, C.-E., Gerringa, L. J. A., Klunder, M. B., Middag, R., Laan, P., Timmermans, K. R., et al. (2010). Speciation of Fe in the Eastern North Atlantic Ocean. Deep-Sea Res. I Oceanogr. Res. Pap. 57, 1444-1453. doi: 10.1016/j.dsr.2010.08.004

Thuróczy, C. E., Gerringa, L. J. A., Klunder, M., Laan, P., Le Guitton, M., and De Baar, H. J. W. (2011a). Distinct trends in the speciation of iron between the shallow shelf seas and the deep basins of the Arctic Ocean. J. Geophys. Res. 116:C10009. doi: 10.1029/2010JC006835

Tian, F., Frew, R. D., Sander, S., Hunter, K. A., and Ellwood, M. J. (2006). Organic iron(III) speciation in surface transects across a frontal zone: The Chatham Rise, New Zealand. Mar. Freshw. Res. 57, 533-544. doi: 10.1071/MF 05209 
van den Berg, C. M. G. (1982). Determination of copper complexation with natural organic ligands in seawater by equilibration with $\mathrm{MnO} 2$ I. Theory Mar. Chem. 11, 307-322. doi: 10.1016/0304-4203(82) 90028-7

van den Berg, C. M. G. (2006). Chemical speciation of iron in seawater by cathodic stripping voltammetry with dihydroxynaphthalene. Anal. Chem. 78, 156-163. doi: $10.1021 /$ ac051441+

van den Berg, C. M. G., and Donat, J. R. (1992). Determination and data evaluation of copper complexation by organic ligands in sea water using cathodic stripping voltammetry at varying detection windows. Anal. Chim. Acta 257, 281-291. doi: 10.1016/0003-2670(92)85181-5

van den Berg, C. M. G., Nimmo, M., Daly, P., and Turner, D. R. (1990). Effects of the detection window on the determination of organic copper speciation in estuarine waters. Anal. Chim. Acta 232, 149-159. doi: 10.1016/S00032670(00)81231-3

Völker, C., and Tagliabue, A. (2015). Modeling organic iron-binding ligands in a three-dimensional biogeochemical ocean model. Mar. Chem. 173, 67-77. doi: 10.1016/j.marchem.2014.11.008
Witter, A. E., Lewis, B. L., and Luther III, G. W. (2000). Iron speciation in the Arabian Sea. Deep-Sea Res. Part II Top. Stud. Oceanogr. 47, 1517-1539. doi: 10.1016/S0967-0645(99)00152-6

Witter, A. E., and Luther, G. W. III. (1998). Variation in Fe-organic complexation with depth in the Northwestern Atlantic Ocean as determined using a kinetic approach. Mar. Chem. 62, 241-258. doi: 10.1016/S0304-4203(98)00044-9

Conflict of Interest Statement: The authors declare that the research was conducted in the absence of any commercial or financial relationships that could be construed as a potential conflict of interest.

Copyright (c) 2016 Caprara, Buck, Gerringa, Rijkenberg and Monticelli. This is an open-access article distributed under the terms of the Creative Commons Attribution License (CC BY). The use, distribution or reproduction in other forums is permitted, provided the original author(s) or licensor are credited and that the original publication in this journal is cited, in accordance with accepted academic practice. No use, distribution or reproduction is permitted which does not comply with these terms. 